\title{
Cancer-Prone Syndrome of Mosaic Variegated Aneuploidy and Total Premature Chromatid Separation: Report of Five Infants
}

Tadashi Kajii, ${ }^{1 *}$ Tatsuro Ikeuchi, ${ }^{2}$ Zeng-Quan Yang, ${ }^{2}$ Yasuhiro Nakamura, ${ }^{3}$ Yoichiro Tsuji, ${ }^{4}$ Kinji Yokomori, ${ }^{5}$ Miyako Kawamura, ${ }^{6}$ Seiichi Fukuda, ${ }^{7}$ Seiki Horita, ${ }^{8}$ and Akihiro Asamoto

${ }^{1}$ Hachioji, Tokyo, Japan

${ }^{2}$ Division of Genetics, Medical Research Institute, Tokyo Medical and Dental University, Tokyo, Japan

${ }^{3}$ Department of Pathology, St. Mary's Hospital, Kurume City, Japan

${ }^{4}$ Department of Pediatrics, Musashino Red Cross Hospital, Tokyo, Japan

${ }_{5}^{5}$ Department of Pediatric Surgery, Japanese Red Cross Medical Center, Tokyo, Japan

${ }^{6}$ Department of Pediatrics, Iwate Prefectural Tonan-no-sono, Iwate, Japan

${ }^{7}$ Department of Neonatology, St. Mary's Hospital, Kurume City, Japan

${ }^{8}$ Division of Pediatrics, Ishikawa Prefectural Central Hospital, Kanazawa City, Japan

${ }^{9}$ Division of Obstetrics and Gynecology, Ishikawa Prefectural Central Hospital, Kanazawa City, Japan

Five infants (two girls and three boys) from four families all had severe pre- and postnatal growth retardation, profound developmental delay, microcephaly, hypoplasia of the brain with Dandy-Walker complex or other posterior fossa malformations, and developed uncontrollable clonic seizures. Four infants developed Wilms tumors, and one showed cystic lesions in bilateral kidneys. All five infants showed variegated mosaic aneuploidy in cultured lymphocytes. In two infants whose chromosomes were prepared by us, $48.5 \%-83.2 \%$ lymphocytes showed total premature chromatid separation (PCS). Their parents had 3.5\%-41.7\% of their lymphocytes in total PCS. The remaining three infants and their parents, whose chromosomes were prepared at outside laboratories, tended to show lower frequencies of total PCS. Another five infants reported with the disorder were reviewed together with the five infants we described. Together, their clinical and cytogenetic manifestations were similar enough to suggest a syndrome. Seven of the 10 infants

Grant sponsor: Special Coordination Funds for Promoting Science and Technology from the Science and Technology Agency of Japan; Grant sponsor: Ministry of Education, Culture, Sports, Science and Technology of Japan; Grant number: 13214030; Grant sponsor: Japan Society for the Promotion of Science; Grant number: 13672374.

*Correspondence to: Dr. Tadashi Kajii, Kuboyama-cho 1-9-3311, Hachioji, Tokyo 192-0023, Japan.

E-mail: tkajii@mbj.sphere.ne.jp

Received 14 December 2000; Accepted 18 June 2001

DOI 10.1002/ajmg.1580 developed proven or probable Wilms tumors. The age at diagnosis of the tumors was younger than usual at 2-16 months. The tumors were bilateral in four infants and unilateral in three infants, and cystic changes were present in six infants. Two infants developed botryoid rhabdomyosarcoma. The carriers of the syndrome are thus liable to tumorigenesis. The possible role of mitotic checkpoint defects, proven in two infants with the syndrome (Matsuura et al. [2000: Am J Hum Genet 69:483-486]), was discussed in connection with tumor development and progression.

(c) 2001 Wiley-Liss, Inc.

KEY WORDS: mosaic variegated aneuploidy; total premature chromatid separation; Dandy-Walker complex; Wilms tumor; botryoid rhabdomyosarcoma; cancer-prone syndrome; mitotic spindle-checkpoint

\section{INTRODUCTION}

Mosaic aneuploidies, especially trisomies, double trisomies, and monosomies involving a variety of chromosomes, called "mosaic variegated aneuploidy" (MVA), have been described in three categories of individuals. They are (1) those with MVA as a sole chromosome abnormality, (2) those with MVA and high frequencies of cells with premature separation of sisterchromatids in all chromosomes, called "total premature chromatid separation" (total PCS), and (3) those with 
MVA and total PCS whose parents have $3 \%$ or more cells with total PCS. The category of isolated MVA has been reported in three pairs of sibs with microcephaly, growth retardation, multiple malformations, and with or without mental retardation [Tolmie et al., 1988; Papi et al., 1989; Flejter et al., 1998] in a sib pair of a 4month-old girl and an induced abortus [Nash et al., 1997] and in a subfertile man without phenotypic abnormalities [Rosensaft et al., 1999]. The category of MVA and total PCS has been reported in three unrelated individuals with microcephaly, growth retardation, severe mental retardation, and other abnormalities [Miller et al., 1990; Warburton et al., 1991; Limwongse et al., 1999]. Their parents were either negative [Miller et al., 1990] or not studied for total PCS [Warburton et al., 1991; Limwongse et al., 1999]. The third category of MVA, total PCS, and parental total PCS has been reported in six unrelated individuals with microcephaly, growth retardation, severe mental retardation, and with or without multiple malformations [Kajii et al., 1998; Kawame et al., 1999; Plaja et al., 2001].

We describe five infants in the third category and review another five infants in the literature. Their clinical manifestations, including malformations in the posterior cranial fossa and frequent Wilms tumor and rhabdomyosarcoma, are similar enough to suggest a syndrome.

\section{CLINICAL REPORTS}

\section{Patient 1}

Patient 1, a boy, was born at full-term to a 37-year-old primigravida mother and a 37-year-old father, both healthy and nonconsanguineous. His birth weight was 2,642 $\mathrm{g}$ (-1.4 SD); length, $44.5 \mathrm{~cm}(-2.8 \mathrm{SD})$; and occipito-frontal head circumference (OFC), $30.5 \mathrm{~cm}$ $(-1.7 \mathrm{SD})$. When referred to us at age 8 weeks with feeding difficulties, he weighed $3,877 \mathrm{~g}$ (-2.4 SD); length, $52.5 \mathrm{~cm}(-2.5 \mathrm{SD})$; and OFC, $31 \mathrm{~cm}(-4.3 \mathrm{SD})$. $\mathrm{He}$ had severe microcephaly but otherwise had no external malformations. Magnetic resonance imaging (MRI) of the brain demonstrated partial hypoplasia of the cerebelllar vermis, a prominent cisterna magna, and an enlarged posterior fossa, but without enlargement of the fourth ventricle.

A 7-cm solid mass was palpable in the right upper abdomen, and abdominal imaging studies showed a tumor in the lower pole of the right kidney. His systolic blood pressure was elevated at $108 \mathrm{~mm}$ of $\mathrm{Hg}$. Urinary protein was positive and contained $8,240 \mu \mathrm{g} / \mathrm{l}$ of $\beta 2$ microglobulin. The plasma renin activity was $350 \mathrm{ng} / \mathrm{ml} / \mathrm{hr}$ (normal 0.3-2.9 ng/ml $/ \mathrm{hr}$ ), and the plasma aldosterone level was $2,600 \mathrm{pg} / \mathrm{ml}$ (normal $35.7-240 \mathrm{pg} / \mathrm{ml}$ ). Serum erythropoietin was increased at $503 \mathrm{mV} / \mathrm{ml}$ (normal $8-36 \mathrm{mV} / \mathrm{ml}$ ). Right nephrectomy was performed at age 9 weeks. Histological examination demonstrated a stage I Wilms tumor, mainly composed of blastema cells and in part of tubular structures, but without cystic changes. Numerous clusters of persistent embryonic cells were noted confined to the periphery of the renal lobe (perilobar nephrogenic rests by Beckwith [1998]). At age 4 months, he developed uncontrollable clonic seizures. He died of pneumonia at age 5 months.

\section{Patient 2}

Patient 2, a girl, was born to a 23-year-old primigravida mother and a 24-year-old nonconsanguineous father after a pregnancy complicated by oligohydramnios and intrauterine growth retardation. The baby was delivered through Caesarian section at 37 weeks of gestation. She weighed $1,634 \mathrm{~g}(-2.8 \mathrm{SD})$, measured $40 \mathrm{~cm}(-3.7 \mathrm{SD})$, and had an OFC of $26 \mathrm{~cm}(-3.9 \mathrm{SD})$. She had neonatal hyperbilirubinemia, and at age 3 months developed frequent, uncontrollable seizures. Intracranial imaging studies showed hypoplasia of the brain, agenesis of the corps callosum, and DandyWalker complex type A [Barkovich et al., 1989] with a hypoplastic cerebellar vermis, an enlarged fourth ventricle, and an enlarged posterior fossa. Abdominal CT at age 10 months showed a multicystic tumor in the left abdominal cavity, whereas the right kidney appeared normal. Left nephrectomy performed at age 11 months produced a multicystic and partially solid, well-differentiated, stage I Wilms tumor that was $12 \times 12 \times 7 \mathrm{~cm}$ [Endo et al., 1999]. She received postoperative chemotherapy.

At age 11 months, she measured $65.7 \mathrm{~cm}(-2.9 \mathrm{SD})$, weighed $9.2 \mathrm{~kg}(+0.4 \mathrm{SD})$, and had an OFC of $52.5 \mathrm{~cm}$ $(+1.6 \mathrm{SD})$. She had bilateral cataracts. Brain MRI at age 3 years indicated advanced internal hydrocephalus with brain atrophy. Now aged 5 years, she is bed-ridden and tube-fed. She is speechless, spastic, and barely reacts to sound.

\section{Patient 3}

Patient 3, a girl, was delivered at 32 weeks of gestation through Cesarean section to a 39-year-old mother and a 40-year-old father, both healthy and nonconsanguineous. Ultrasonography at 6 months of pregnancy revealed fetal growth retardation and microcephaly. At birth, she weighed $1,160 \mathrm{~g}(-2.4$ $\mathrm{SD})$, measured $37 \mathrm{~cm}(-1.5 \mathrm{SD})$, and had an OFC of $22.5 \mathrm{~cm}(-3.8 \mathrm{SD})$. When transferred to us the following day, she had respiratory distress, growth retardation and severe microcephaly with a closed large fontanel, bilateral cataracts and right microphthalmia, a webbed neck, and generalized hypotonia. MRI of the brain at age 11 days showed hypoplasia of the brain and DandyWalker complex. At age 6 weeks, she developed uncontrollable clonic seizures. Abdominal graphic studies at age 7 months demonstrated a multicystic tumor in the upper pole of the right kidney. Right nephrectomy was performed and documented a stage I polycytic Wilms tumor with favorable histology. The cysts were surrounded by blastema cells, tubular or glomerular elements, stromal cells, and interspersed striated muscles. Within the renal lobes there were areas consisting of multiple cell types, including abundant immature and mature stroma (intralobar nephrogenic rests by Beckwith [1998]). When discharged at age 10 months, she weighed $3.54 \mathrm{~kg}$ 
( $-5.8 \mathrm{SD})$, measured $54 \mathrm{~cm}(-7.8 \mathrm{SD})$, and had an OFC of $33.7 \mathrm{~cm} \mathrm{(-6.2} \mathrm{SD).} \mathrm{She} \mathrm{died} \mathrm{at} \mathrm{home} 6$ months later.

Her two older sisters both had had severe microcephaly, pre- and postnatal growth retardation, severe mental retardation, and bilateral cataracts; developed seizures and bilateral, well-differentiated polycystic nephroblastoma; died at ages 12 months and 16 months, respectively; and were autopsied [Nakamura et al., 1981, 1985]. The first sister had arrhinencepaly, agenesis of the corpus callosum, hypoplasia of the cerebellum, and botryoid sarcoma of the vagina extending to the bladder [Nakamura et al., 1981]. Her chromosomes were reportedly normal. The second sister had trisomy 8 in $16 \%$ of the cells analyzed [Nakamura et al., 1985]. Autopsy showed DandyWalker complex type A with a large cyst in the posterior fossa connected to the fourth ventricle, defect of the lower cerebellar vermis, and moderate hydrocephalus. The brain was small and pachygyric.

\section{Patient 4}

Patient 4 , a boy, was born at 40 weeks of gestation to a 25-year-old mother and a 26-year-old father, both healthy and nonconsanguineous. His birth weight was $2,142 \mathrm{~g}$ (-2.6 SD); length, $42 \mathrm{~cm}(-4.2 \mathrm{SD})$; and OFC, $28.4 \mathrm{~cm}(-2.8 \mathrm{SD})$. MRI of the brain in the neonatal period showed Dandy-Walker complex type A with hydrocephalus, hypoplasia of the brain, and partial agenesis of the corpus callosum. He was referred to us at age 3 months with a polyp-shaped mass at the urethral orifice of the penis. Ultrasonography, CT, and cystography indicated a grape-shaped tumor extending from the bladder to the posterior urethra. A biopsy specimen from the tumor was diagnosed as botryoid rhabdomyosarcoma, and the tumor was resected at age 7 months. A mass was palpable in the left abdomen, and abdominal CT showed multicystic, partially solid lesions in both kidneys, more pronounced on the left than on the right. He was treated with three courses of chemotherapy with vincristine, actinomycin D, and cyclophosphamide. At age 4 months, he developed uncontrollable seizures. Hydrocephalus progressed and he died at age 13 months. Autopsy was not granted.

\section{Patient 5}

Patient 5 , a younger brother of patient 4 , was born 2 years later at 41 weeks of gestation. His birth weight was $1,985 \mathrm{~g}$ (-3.4 SD); length, $40 \mathrm{~cm}(-5.4 \mathrm{SD})$; and $\mathrm{OFC}, 28.4 \mathrm{~cm}(-2.8 \mathrm{SD})$. MRI of the brain demonstrated Dandy-Walker complex type B [Barkovich et al., 1989], enlarged ventricles, hypoplasia of the brain, and hypoplasia of the corpus callosum. Abdominal sonography showed multicytic lesions in bilateral kidneys. At age 4 months, he developed uncontrollable clonic seizures. The renal tumors, especially that on the right, increased in size. He died at age 7 months of hemorrhage into the tumors. A biopsy specimen taken after death from the right kidney indicated polycystic nephroblastoma.

\section{CYTOGENETIC STUDIES}

Peripheral blood lymphocytes from patients 1 and 2 and their parents were cultured in RPMI1640, arrested for $3 \mathrm{hr}$ with $0.4 \mu \mathrm{g} / \mathrm{ml}$ of Colcemid, treated at $32^{\circ} \mathrm{C}$ for $20 \mathrm{~min}$ in $0.075 \mathrm{M} \mathrm{KCl}$ maintained in a water bath, and fixed in 1:3 acetic methanol. Chromosomes were spread onto glass slides at $23^{\circ} \mathrm{C}-25^{\circ} \mathrm{C}$ room temperature under $50 \%-55 \%$ ambient humidity. In some of the repeat lymphocyte cultures, cells were arrested with $0.04 \mu \mathrm{g} /$ $\mathrm{ml}$ of Colcemid for $2 \mathrm{hr}$, treated with $0.075 \mathrm{M} \mathrm{KCl}$ at $37^{\circ} \mathrm{C}$ for $20 \mathrm{~min}$ in a water bath, and fixed, and chromosome slides were prepared. The chromosomes were either solid-stained or G-banded. At least 200 metaphases in each culture were scored for total PCS. Both methods resulted in comparable frequencies of cells with total PCS. The chromosomes of patients $3-5$ and their parents were processed at outside laboratories but analyzed by us. Those from patient 3 and her parents were treated with $0.075 \mathrm{M} \mathrm{KCl}$ at room temperature for $10 \mathrm{~min}$. Those from patients 4 and 5 were processed at yet other laboratories, but their processing condition is unknown to us. Their parents were unavailable for study.

Table I summarizes the results of chromosome analyses of cultured lymphocytes in the five infants and their parents. Patients 1-5 all showed 9\%-32\% aneuploid cells, especially trisomies and double trisomies, but also monosomies. Virtually every chromosome was involved in the aneuploidy, but trisomies 7 and 8 were relatively frequent. Their parents, on the other hand, did not show increased aneuploid cells. Patients 1 and 2 , whose chromosomes were processed by us, showed $48.5 \%$ and $83.2 \%$ cells, respectively, in total PCS (Fig. 1). Their parents had 3.5\%-41.7\% cells in total PCS.

The chromosomes from patient 3 and her parents were prepared at an outside laboratory and treated with hypotonic $\mathrm{KCl}$ at room temperature for $10 \mathrm{~min}$ : the patient showed $10.5 \%$ cells in total PCS, and her parents were negative for the finding. Patient 4, whose chromosomes were prepared at another outside laboratory, showed only $36 \%$ of cells in total PCS. These lower frequencies of cells in total PCS processed at outside laboratories were interpreted as a reflection of technical difference in chromosome preparation, especially the lower temperature and shorter duration of hypotonic $\mathrm{KCl}$ treatment.

Cultured skin fibroblasts from patient 1 had 35\% cells in mosaic aneuploidy, of which trisomies 7 and 18 were frequent, and 50\% cells in total PCS (Table I). Blymphoblastoid cell lines were prepared from patients 1 and 2 and their parents, using EB virus stimulation. Their chromosomes were studied within 4 weeks of the initiation of culturing. Cells were arrested with $0.1 \mu \mathrm{g} /$ $\mathrm{ml}$ of Colcemid for $3 \mathrm{hr}$ and treated with $0.075 \mathrm{M} \mathrm{KCl}$ at $37^{\circ} \mathrm{C}$ for $20 \mathrm{~min}$. The lymphoblastoid cells from patients 1 and 2 included $25 \%$ and $39 \%$ cells in mosaic aneuploidy and $78.3 \%$ and $53.7 \%$ cells in total PCS, respectively (Table II). The cells from their parents showed no increase of aneuploid cells, but had 3.8\%$5.9 \%$ cells in total PCS. 
TABLE I. Chromosome Characteristics in Four Families

\begin{tabular}{|c|c|c|c|c|c|c|c|c|}
\hline & \multirow[b]{2}{*}{ Age } & \multirow[b]{2}{*}{ Tissue } & \multirow{2}{*}{$\begin{array}{l}\text { Cells } \\
\text { counted }\end{array}$} & \multicolumn{4}{|c|}{ Chromosome counts } & \multirow[b]{2}{*}{ Total PCS (\%) } \\
\hline & & & & $\leq 45$ & 46 & 47 & $\geq 48$ & \\
\hline \multicolumn{9}{|l|}{ Family 1} \\
\hline Father & $37 \mathrm{yrs}$ & Lymphocytes & 36 & & 36 & & & $5-8.5$ \\
\hline Mother & 37 yrs & Lymphocytes & 41 & 3 & 38 & & & 3.5 \\
\hline \multirow[t]{2}{*}{ Patient 1} & $2 \mathrm{mo}$ & Lymphocytes & 33 & & 30 & $3^{\mathrm{c}}$ & & $48.5 ; 73.5$ \\
\hline & & Skin fibroblasts & 37 & 3 & 24 & $10^{\mathrm{d}}$ & & 50 \\
\hline \multicolumn{9}{|l|}{ Family 2} \\
\hline Father & & Lymphocytes & 36 & & 36 & & & $4.1 ; 13.2$ \\
\hline Mother & & Lymphocytes & 38 & 3 & 35 & & & $24.7 ; 41.7$ \\
\hline Patient 2 & 3 yrs & Lymphocytes & 53 & 2 & 40 & $8^{\mathrm{e}}$ & $3^{\mathrm{e}}$ & 68,$5 ; 83.2$ \\
\hline \multicolumn{9}{|l|}{ Family 3} \\
\hline Father & & Lymphocytes $^{\mathrm{a}}$ & 30 & 3 & 27 & & & 0 \\
\hline Mother & $42 \mathrm{yrs}$ & Lymphocytes $^{\text {a }}$ & 30 & 3 & 27 & & & 0 \\
\hline Patient 3 & & Lymphocytes $^{\mathrm{a}}$ & 65 & 4 & 52 & $7^{\mathrm{f}}$ & $2^{\mathrm{f}}$ & 10.5 \\
\hline \multicolumn{9}{|l|}{ Family 4} \\
\hline Patient 4 & 8 days & Lymphocytes $^{\mathrm{a}}$ & 38 & 3 & 31 & $2^{\mathrm{g}}$ & $2^{\mathrm{g}}$ & 36 \\
\hline Patient 5 & 0 day & Lymphocytes $^{\text {b }}$ & 19 & 3 & 13 & $2^{\mathrm{h}}$ & $1^{\mathrm{h}}$ & $?$ \\
\hline
\end{tabular}

${ }^{\mathrm{a}}$ Chromosome slides were prepared at an outside laboratory and analyzed by us.

${ }^{\mathrm{b}}$ Chromosome photographs were prepared at an outside laboratory and analyzed by us.

$c^{c}+7,+20,+22$ in one cell each.

$\mathrm{d}_{+7}$ in 5 cells; +18 in 3 cells; +19 in one cell $;-16,+19,+20$ in one cell.

${ }^{e}+6$ in 2 cells; +7 in 2 cells; $+7,+9,+11,+13,+22$, and + mar 1 in one cell each; $-19,+4,+16$ in one cell each $;+3,+6,+11,+18$ in one cell $;+7, \mathrm{t}(3 ; 13)$ in one cell.

${ }^{\mathrm{f}}+\mathrm{C}$ in 4 cells; $+3,+4,+16,+18$, and $+\mathrm{F}$ in one cell each; $+\mathrm{C},+21$ in one cell.

$\mathrm{g}_{+}+15$ and $+\mathrm{Y}$ in one cell each; $+8,+8$ in one cell; $-5,+14,+17+19$ in one cell.

$\mathrm{h}_{+\mathrm{B}}$ and +8 in one cell each; $+8,+8$ in one cell.

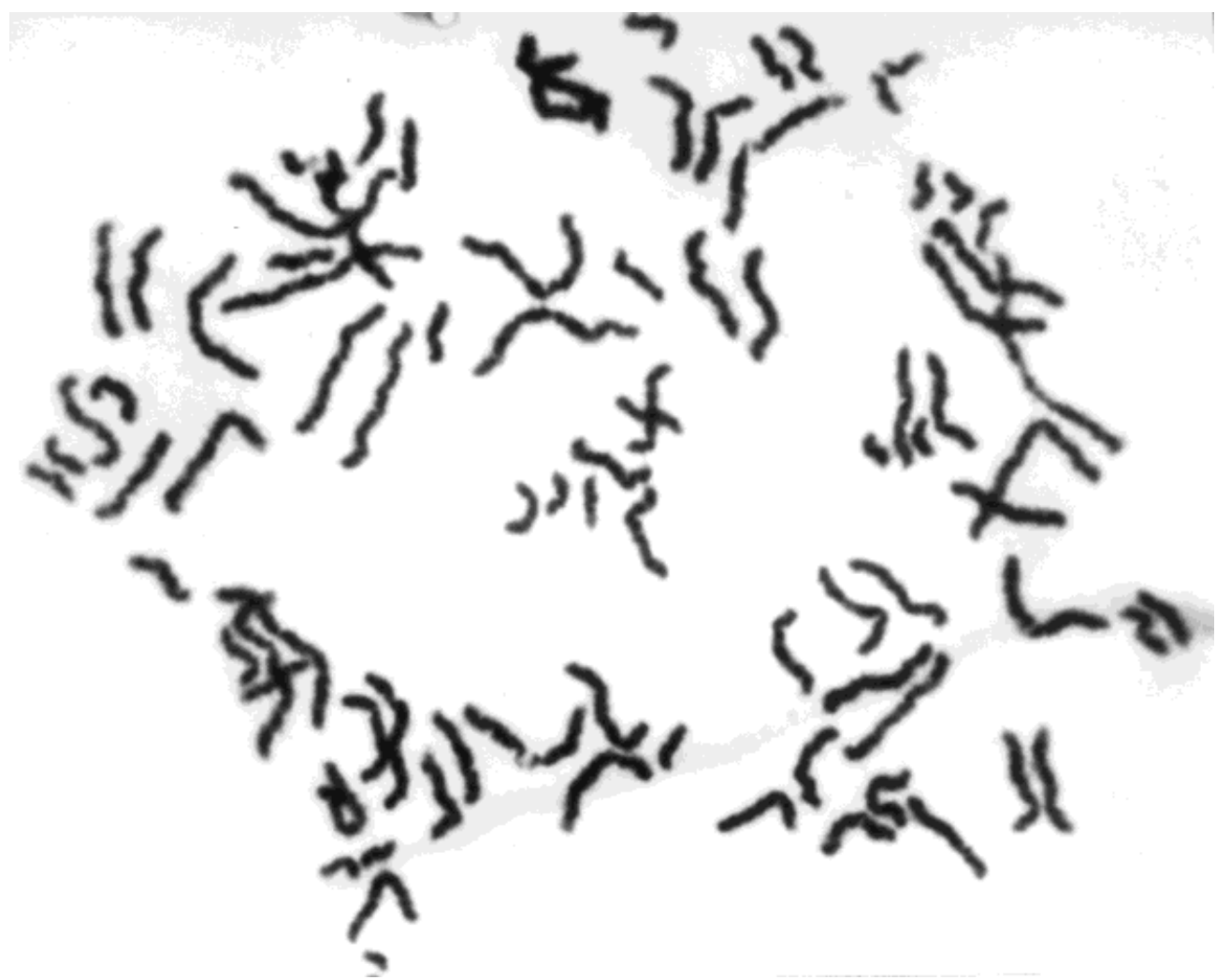

Fig. 1. A metaphase with total PCS from cultured blood lymphocytes of patient 1 . 
TABLE II. Chromosomes in Lymphoblastoid Cell Lines

\begin{tabular}{|c|c|c|c|c|c|c|}
\hline & \multirow{2}{*}{$\begin{array}{c}\text { Cells } \\
\text { counted }\end{array}$} & \multicolumn{4}{|c|}{ Chromosome counts } & \multirow{2}{*}{$\begin{array}{c}\text { Total } \\
\text { PCS }(\%)\end{array}$} \\
\hline & & $\leq 45$ & 46 & 47 & $\geq 48$ & \\
\hline \multicolumn{7}{|l|}{ Family 1} \\
\hline Father & 37 & 1 & 36 & & & 5.0 \\
\hline Mother & 35 & & 35 & & & 3.8 \\
\hline Patient 1 & 40 & 1 & 30 & $7^{\mathrm{a}}$ & $2^{\mathrm{a}}$ & 78.3 \\
\hline \multicolumn{7}{|l|}{ Family 2} \\
\hline Father & 32 & 1 & 31 & & & 4.4 \\
\hline Mother & 33 & 1 & 31 & $1^{\mathrm{b}}$ & & 5.9 \\
\hline Patient 2 & 54 & 4 & 33 & $14^{\mathrm{c}}$ & $3^{\mathrm{c}}$ & 53.7 \\
\hline
\end{tabular}

\section{DISCUSSION}

The clinical and cytogenetic findings in the five infants we described are summarized in Table III, together with another five infants in the literature with similar clinical and cytogenetic findings. Together, their clinical and cytogenetic manifestations are similar enough to suggest a syndrome. They included (1) more than $50 \%$ of mitotic lymphocytes with total PCS (7 in 9 infants), (2) mosaic variegated aneuploidy (10/10), (3) pre- and postnatal growth retardation and profound developmental delay (10/10), (4) severe microcephaly (10/10), (5) hypoplasia of the brain with Dandy-Walker complex or other malformations of the posterior fossa (10/10), (6) uncontrollable clonic seizures (8/10), and (7) both parents with $3 \%$ or more mitotic lymphocytes in total PCS (7/8). Less frequent clinical manifestations included minor facial abnormalities, bilateral cataracts, microphthalmia, cleft palate, ambiguous genitalia in males, and skin abnormalities. Of the 10 infants, 7 developed definite or probable Wilms tumor, and 2 showed botryoid rhabdomyosarcoma. The disorder is thus prone to tumor formation. Seven infants died within 3 years of age, and three are alive at reporting, at ages 5 years, 9 months, and 5 months, respectively.

The seven infants who developed definite or probable Wilms tumors are presented in Table IV. The tumors were unilateral in three infants and bilateral in four infants. Approximately 5\% of Wilms tumors are known to involve both kidneys either at presentation or later [Breslow et al., 1988]. Thus, bilateral involvement was much more frequent in the present series. The age at diagnosis of Wilms tumor in the nine infants was 2-16 months, younger than the mean age of 29.5 months for males with bilateral tumors and 32.6 months for females with bilateral tumors [Breslow et al., 1993]. Six infants in the present series had polycystic lesions, whereas one (patient 1) had a solid tumor. The cystic elements in polycystic nephroblastomas result from progressive dilatation of differentiated tubules and so indicate the presence of well-differentiated tubular elements in the tumors [Christ, 1968]. Both intra- and perilobar nephrogenic rests were observed in the present series (patients 1 and 3) [Beckwith, 1998]. Summarizing these findings, most of the Wilms tumors in the present series were noted at a young age, bilateral, polycystic, and showed favorable histology.

Of the 10 infants, 5 boys and 5 girls were affected. Two older sisters of patient 3 were similarly affected, although their cytogenetic analyses were incomplete [Nakamura et al., 1981, 1985]. Patients 4 and 5 were brothers. The parents in the nine families were all phenotypically normal. The clinical manifestations of the disorder thus appear to be autosomal recessive. This, however, is not contradictory to our previous suggestion that the total PCS trait is a conditional codominant trait in which the putative homozygous state is more severe than the heterozygous state [Kajii et al., 1998].

As mentioned earlier, three categories of individuals have been reported with mosaic variegated aneuploidy (MVA). They are (1) those with MVA as a sole chromosome abnormality, (2) those with MVA and high frequencies of cells with total PCS, and (3) those with MVA and total PCS whose parents have $3 \%$ or more cells in total PCS. Of the five infants we described and another five infants we reviewed, at least seven belong to the third category. The clinical manifestations of the individuals in the three categories varied widely, but most of them shared microcephaly, growth retardation, and severe mental retardation. Some of them developed malignancies. A 7-year-old boy reported by Limwongse et al. [1999] with MVA and cells in total PCS developed embryonal rhabdomyosarcoma of the palate. Patient 1 described by Plaja et al. [2001] died at age 42 years of acute nonlymphocytic leukemia. A 3-year-old boy with MVA reported in an abstract by Jacquemont et al. [2000] died of lymphoblastic leukemia. We assume that most if not all individuals in the three categories belong to the same disorder in view of their clinical similarities. The 10 infants we reviewed are likely to represent the severe end of the wide clinical spectrum. The apparent absence or low frequencies of cells in total PCS in some of these individuals or their parents are 


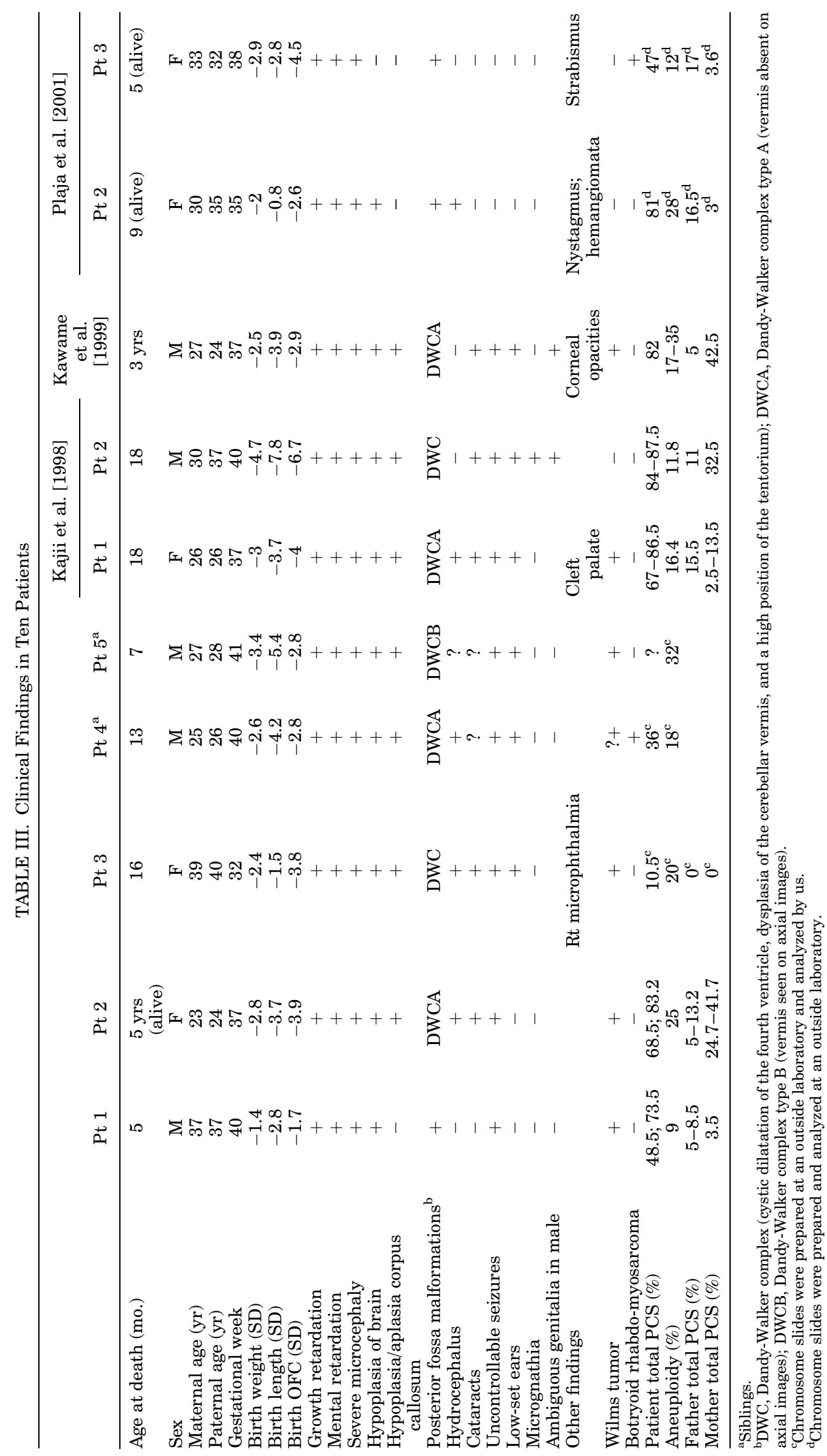


TABLE IV. Wilms Tumors in Seven Patients

\begin{tabular}{|c|c|c|c|c|c|c|}
\hline & \multirow[b]{2}{*}{ Sex } & \multicolumn{2}{|c|}{ Graphic abnormalities } & \multirow{2}{*}{$\begin{array}{l}\text { Age at diagnosis } \\
\text { (mo) }\end{array}$} & \multicolumn{2}{|c|}{ Surgical intervention } \\
\hline & & Right kidney & Left kidney & & Right kidney & Left kidney \\
\hline Patient 1 & M & Solid tumor & - & 2 & Nephrectomy $^{\mathrm{a}}$ & - \\
\hline Patient 2 & $\mathrm{~F}$ & - & Polycystic & 11 & - & Nephrectomy $^{b}$ \\
\hline Patient 3 & $\mathrm{~F}$ & Polycystic & - & 7 & Nephrectomy ${ }^{\mathrm{c}}$ & - \\
\hline Patient 4 & $\mathrm{M}$ & Polycystic & Polycystic & - & - & - \\
\hline Patient 5 & M & Polycystic & Polycystic & 7 & Biopsy $^{\mathrm{d}}$ & Biopsy $^{\mathrm{e}}$ \\
\hline Kajii et al. [1998], Pt 1 & $\mathrm{~F}$ & Cystic & Polycystic & 15 & Aspiration of cyst fluid ${ }^{f}$ & Biopsy $^{g}$ \\
\hline Kawame et al. [1999] & $\mathrm{M}$ & Polycystic & Polycystic & 10 & Tumor excision ${ }^{\mathrm{h}}$ & Nephrectomy \\
\hline
\end{tabular}

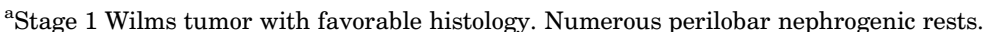

${ }^{b}$ Multicystic, partially solid, well-differentiated, stage 1 Wilms tumor.

${ }^{\mathrm{c}}$ Stage 1 multicystic Wilms tumor with favorable histology. Intralobar nephrogenic rests.

${ }^{\mathrm{d}}$ Nephroblastoma, focal nephroblastic type.

${ }^{\text {e}}$ Cystic nephroblastoma.

${ }^{\mathrm{f}}$ No tumor cells in the cyst fluid.

${ }^{g}$ Stage 1 Wilms tumor with favorable histological signs.

${ }^{\text {h}}$ Wilms tumor, nephroblastic type.

likely to reflect technical difference in chromosome preparation. Alternatively, the cells in total PCS in some instances may have been overlooked during lowpower scanning.

Matsuura et al. [2000] demonstrated in cultured fibroblasts from two infants with the disorder (patient 1 from this study and the patient reported by Kawame et al. [1999]) that these cells are insensitive to a Colcemid-induced mitotic checkpoint to enter G1 and S phases without sister chromatid separation and cytokinesis. Their fibroblasts also had aneuploidy and total PCS. Both infants developed Wilms tumors. The occurrence of aneuploid cells in these mitotic checkpoint-insensitive fibroblasts may be due to premature anaphase even in the absence of spindle inhibitor. Cells with experimentally produced heterozygous deletion of $M A D 2$, a mitotic checkpoint gene, have shown aneuploidy and total PCS [Michel et al., 2001]. $M A D 2^{+/-}$ mice developed papillary lung adenocarcinomas of a high rate after long latencies, implicating defects in the mitotic checkpoint in tumorigenesis. The similarities of the human cancer-prone syndrome we described and the murine lung tumors are intriguing. They differ, however, in that the carriers of the human cancers are likely to be homozygous for the presumed mitotic checkpoint gene, whereas the mice that develop lung tumors are heterozygous for MAD2 mutation. Detection of the gene for the human cancer-prone disorder we described should clarify the role of mitotic checkpoints in tumor initiation and progression.

\section{ACKNOWLEDGMENTS}

We thank the relatives of the five infants for their cooperation, Dr. H. Misu for allowing us to study histological slides from patient 1 in Kajii et al. [1998], and Ms. Satoh, Mr. Itoh, and Ms. K. Ikawa for providing us with archive chromosome slides.

\section{REFERENCES}

Barkovich AJ, Kjos BO, Norman D, Edwards MS. 1989. Revised classification of posterior fossa cysts and cystlike malformations based on the results of multiple NR imaging. Am J Neuroradiol 153:977988 .
Beckwith JB. 1998. Nephrogenic rests and the pathogenesis of Wilms tumor: developmental and clinical considerations. Am J Med Genet $79: 268-273$.

Breslow NE, Beckwith JB, Ciol M, Shaples K. 1988. Age distribution of Wilms tumor: report of the National Wilms Tumor Study Cancer Research 48:1653-1657.

Breslow N, Olshan A, Beckwith JB, Green DM. 1993. Epidemiology of Wilms tumor. Med Pediatr Oncol 21:172-181.

Christ ML. 1968. Polycystic nephroblastoma. J Urol 98:570-575.

Endo K, Fujii Y, Mukaida M, Kawazoe K, Takano N, Endo M, Masuda T. 1999. A patient with cystic Wilms tumor and multiple anomalies [In Japanese]. Childhood Cancer 36:217-221.

Flejter WL, Issa R, Sullivan BA, Carey JC, Brothman AR. 1998. Variegated aneuploidy in two siblings: phenotype, genotype, CENP-E analysis, and literature review. Am J Med Genet 75:45-51.

Jacquemont S, Boceno M, Genevieve D, Rival JM, Mechinau F, David A. 2000. There is high malignancy risk in mosaic variegated aneuploidy syndrome. Am J Hum Genet 67 ( Suppl 2):A767.

Kajii T, Kawai T, Takumi T, Misu H, Mabuchi O, Takahashi Y, Tachino M, Nihei F, Ikeuchi T. 1998. Mosaic variegated aneuploidy with multiple congenital abnormalities: homozygosity for total premature chromatid separation trait. Am J Med Genet 78:245249.

Kawame H, Sugio Y, Fuyama Y, Hayashi Y, Suzuki H, Kurosawa K, Maekawa K. 1999. Syndrome of microcephaly, Dandy-Walker malformation, and Wilms tumor caused by mosaic variegated aneuploidy with premature centromere division (PCD): report of a new case and review of the literature. J Hum Genet 44:219-224.

Limwongse C, Schwartz S, Bocian M, Robin NH. 1999. Child with mosaic variegated aneuploidy and embryonal rhabdosarcoma. Am J Med Genet 82:20-24.

Matsuura S, Ito E, Tauchi H, Komatsu K, Ikeuchi T, Kajii T. 2000 Chromosomal instability syndrome of total chromatid separation with mosaic variegated aneuploidy is defective in mitotic spindle checkpoint. Am J Hum Genet 67:483-486.

Michel LS, Liberal V, Chatterjee A, Kirchwegger R, Pasche B, Gerald W, Dobles M, Sorger PK, Marty VVVS, Benezra R. 2001. MAD2 haploinsufficiency causes premature anaphase and chromosome instability in mammalian cells. Nature 409:355-359.

Miller K, Müller W, Winkler L, Hadam MR, Ehrlich JHH, Flatz SD. 1990 Mitotic disturbance associated with aneuploidies. Hum Genet 84:361364 .

Nakamura Y, Nakashima T, Nakashima H, Hashimoto T. 1981. Bilateral cystic nephroblastoma and botryoid sarcoma involving vagina and urinary bladder in a child with microcephaly, arhinencepahly, and bilateral cataracts. Cancer 48:1012-1015.

Nakamura Y, Nakashima H, Fukuda S, Hashimoto T, Maruyama M. 1985. Bilateral cystic nephroblastoma and multiple malformations with trisomy 8 mosaicism. Hum Pathol 16:754-756. 
Nash RN, Willatt LR, Andrews TA, Green AJ. 1997. Recurrent multiple aneuploidies: a family with autosomal recessive failure of mitotic control. Am J Hum Genet 61 ( Suppl):A136.

Papi L, Montali E, Marconi G, Guazelli R, Bigozzi U, Maraschio P, Zuffardi O. 1989. Evidence for human mitotic mutant with pleiotropic effect. Ann Hum Genet 53:243-248.

Plaja A, Vendrell T, Smeets D, Sarret E, Gili T, Català V, Mediano C, Scheres JMJC. 2001. Variegated aneuploidy related to premature centromere division (PCD) is expressed in vivo and is a cancer-prone disease. Am J Med Genet 98:216-223.
Rosensaft J, Prilusky C, Dor J, Voskobonik N, Vinkler H, Gelman-Kohan Z. 1999. Multiprobe FISH analysis of variegated mosaicism in a subfertile man. Cytogenet Cell Genet 85:42.

Tolmie JL, Boyd E, Batstone P, Ferguson-Smith ME, Al Roomi L, Connor JM. 1988. Siblings with chromosome mosaicism, microcephaly, and growth retardation: the phenotypic expression of a human mitotic mutant? Hum Genet 80:197-200.

Warburton D, Anyane-Yeboa K, Taterka P, Yu C, Olsen D. 1991. Mosaic variegated aneuploidy with microcephaly: a new human mitotic mutant? Ann Genet 34:287-292. 